\title{
Penerapan Self Assessment, Pengetahuan Wajib Pajak, Pemeriksaan Pajak dan pada Kepatuhan Wajib Pajak
}

\author{
Eliyah $^{1}$, Arles P. Ompusungu ${ }^{2}$, Nur Hidayat ${ }^{3}$ \\ 1,2 Universitas Pancasila, Jl. Raya Lenteng Agung, Jagakarsa, Jakarta Selatan, 12640 \\ ${ }^{3}$ Universitas Jenderal Achmad Yani, Jl. Terusan Jenderal Gatot Subroto, PO BOX 807 Bandung, 40285
}

\section{N F O A R T I K E L JEL Classification:} $\mathrm{H} 26$

\section{Keywords:}

Self assessment, pengetahuan Wajib Pajak, pemeriksaan pajak, kepatuhan Wajib Pajak, path analysis.

\section{A $B$ S S T R A $\boldsymbol{C}$ T}

Taxpayer compliance is influenced by severalfactors such as the application of self assessment, knowledge taxpayer and tax audit. The purpose of this study was to determine the effect of the application of self assessment and knowledge taxpayer to tax audit and its impact on tax compliance. The population in this study is th-e taxpayer Hotel and Restaurant in South Jakarta Administration City Region for period 2008 - 2012. The sample used in this study were 200 Hotel and Restaurant taxpayer. Methods of data analysis and path analysis with the help of software Lisrel 8.51. Qualitative data were collected through a questionnaire was converted into interval data through the transformation of MSI so it can be analyzed statistically. Statistical tests using path analysis test value obtained on the first sub structure testing result that directly and indirectly influence the implementation of self assessment, knowledge taxpayer to tax audits by $38.20 \%$ with positive direction. The second sub structure testing result that directly and indirectly influence the implementation of self assessment, knowledge taxpayer and tax audits on tax compliance of $60.45 \%$ with positive direction.

\section{A B S T R A K}

Kepatuhan Wajib Pajak sangat dipengaruhi oleh beberapa faktor diantaranya adalah penerapan self assessment, pengetahuan wajib pajak dan pemeriksaan pajak. Tujuan penelitian ini untuk mengetahui pengaruh penerapan self assessment dan pengetahuan Wajib Pajak terhadap pemeriksaan pajak dan dampaknya pada kepatuhan Wajib Pajak. Populasi dalam penelitian ini adalah Wajib Pajak Hotel dan Restoran di Wilayah Kota Administrasi Jakarta Selatan untuk periode 2008-2012. Sampel yang digunakan dalam penelitian ini sebanyak 200 Wajib Pajak Hotel dan Restoran. Metode analisis data menggunakan analisis deskripsi dan analisis jalur (Path Analysis) dengan bantuan software Lisrel 8.51. Data kualitatif yang dikumpulkan melalui kuesioner dikonversi menjadi data interval melalui transformasi MSI sehingga dapat dianalisis secara statistik. Hasil pengujian statistik menggunakan path analysis (analisa jalur) diperoleh nilai pada pengujian sub struktur pertama yaitu pengaruh langsung maupun tidak langsung penerapan self assessment dan pengetahuan Wajib Pajak terhadap pemeriksaan pajak sebesar 38,20\% dengan arah yang positif. Hasil pengujian sub struktur kedua yaitu pengaruh langsung dan tidak langsung penerapan self assessment, pengetahuan Wajib Pajak dan pemeriksaan pajak terhadap kepatuhan Wajib Pajak sebesar $60,45 \%$ dengan arah yang positif. 


\section{Pendahuluan}

Tingkat kepatuhan Wajib Pajak hotel dan restoran di wilayah Kota Administrasi Jakarta Selatan pada umumnya masih rendah. Berdasarkan rekapitulasi laporan tahunan Tahun 2012 dari Sudin Pelayanan Pajak Jakarta Selatan, jumlah Wajib Pajak yang mengisi dan melaporkan SPT seharusnya adalah 890 wajib pajak, tetapi $47,3 \%$ tingkat kepatuhannya dinilai masih rendah yang dapat mengakibatkan penerimaan pajak daerah menjadi tidak optimal. Upaya untuk meningkatkan kepatuhan Wajib Pajak tersebut melalui penegakkan hukum (law enforcement).

Pemeriksaan pajak merupakan salah satu bentuk penegakkan hukum (law enforcement) yang dilakukan pemerintah didalam kerangka system self assessment. Bentuk lainnya adalah penyidikan pajak(taxinvestigation) danpenagihan pajak (tax collection). Melalui pemeriksaan pajak tercapai peningkatan kepatuhan Wajib Pajak dan dapat memberikan deterrent effect kepada Wajib Pajak sehingga kepatuhan didalam pemenuhan kewajibannya dibidang perpajakan menjadi lebih baik dan dilakukan secara suka rela (Hutagaol, 2007).

Sistem self assessment memberikan keleluasaan kepada Wajib Pajak untuk menghitung, membayar dan melaporkan sendiri jumlah pajak yang harus dibayar, sedangkan fungsi fiskus hanya sebagai penyuluh, pengawas dan melakukan pemeriksaan. Ketika Wajib Pajak dikemudian hari terbukti melakukan kesalahan, maka ancamannya bukan saja pada sanksi administratif namun bisa sampai pada tingkat pemidanaan. Dengan demikian keberhasilan sistem self assessment sangat tergantung kepada kesadaran Wajib Pajak dan law enforcement yang dilakukan Pemerintah.

Menurut Rustiyaningsih (2011), Penerimaan pajak dipengaruhi oleh pertumbuhan ekonomi, yang akan meningkatkan pendapatan masyarakat sehingga mempunyai kemampuan secara finansial untuk membayar pajak. Melalui peningkatan kepatuhan Wajib Pajak diharapkan adanya penerimaan pajak yang meningkat setiap tahun.
Diperlukan dana untuk membiayai penyelenggaraan Pemerintahan. Hal ini sejalan dengan Ketentuan Umum dan Tata Cara Perpajakan yaitu Undang- Undang Nomor 28 Tahun 2009 yang menyatakan bahwa pajak adalah kontribusi wajib kepada Negara yang terutang oleh orang pribadi atau badan yang bersifat memaksa berdasarkan Undang-Undang, dengan tidak mendapatkan imbalan secara langsung dan digunakan untuk keperluan Negara bagi sebesarbesar kemakmuran rakyat.

Darmayanti (2004) menunjukkan bahwa penerapan self assessment system pada pajak daerah akan efektif jika kepatuhan sukarela pada masyarakat telah terbentuk. Penerapan sistem self assessment akan berpengaruh terhadap kepatuhan wajib pajak karena dalam pelaksanaannya Wajib Pajak harus memiliki kesadaran, kejujuran, hasrat membayar dan kedisiplinan (Anggraeni, 2007).

Pengetahuan wajib pajak turut mempengaruhi kepatuhan wajib pajak dalam melaksanakan kewajiban perpajakannya. Hal ini disebabkan karena wajib pajak memiliki kemampuan dan karakteristik yang tidak sama. Hasil penelitian Utami et all (2012) menyebutkan bahwa tingkat pengetahuan wajib pajak yang belum memadai tentang ketentuan pelaksanaan Undang-Undang Pajak akan mempengaruhi kepatuhan wajib pajak secara sukarela. Nurmantu (2005) menjelaskan bahwa semakin tinggi pendidikan wajib pajak maka akan semakin mudah bagi mereka untuk memahami peraturan perpajakan.

Tidak meratanya tingkat pengetahuan wajib pajak dalam melaksanakan kewajiban perpajakan menyebabkan ketidakpatuhan wajib pajak dalam pelaksanaan sistem self assessment dapat diantisipasi dengan melakukan upaya intensifikasi pemeriksaan terhadap wajib pajak yang memenuhi kriteria untuk diperiksa. Apabila fungsi pengawasan terhadap kepatuhan wajib pajak berjalan efektif, maka jumlah pajak yang terutang yang dilaporkan oleh wajib pajak dalam SPT nya seharusnya dapat diketahui kebenarannya (Hutagaol, 2007:3). Fungsi pengawasan yang dapat dijalankan untuk meningkatkan kepatuhan Wajib Pajak dalam 3 bentuk yaitu; 1) pemeriksaan 
pajak, 2) penyidikan pajak, 3) penagihan pajak.

Menurut Miladia (2010) kesadaran dan kepatuhan wajib pajak dalam memenuhi kewajiban perpajakannya mempengaruhi peningkatan penerimaan pajak. Moralitas sebagai nilai-nilai individu yang berhubungan dengan kemauan untuk membayar pajak perlu ditingkatkan sehingga memperbaiki tingkat kepatuhan masyarakat wajib pajak dalam melaksanakan ketentuan perpajakan (Sari, 2007).

Penerimaan pajak daerah dari sektor Pajak hotel dan restoran berperan penting bagi penerimaan daerah DKI Jakarta. Penerimaan tersebut belum sepenuhnya mencerminkan penerimaan yang optimal bila dibandingkan dengan potensi yang ada. Penelitian mengenai pengaruh penerapan self assessment dan pengetahuan wajib pajak terhadap pemeriksaan pajak serta dampaknya bagi kepatuhan wajib pajak dianggap relevan sebagai kajian secara ilmiah. Penelitian ini berupaya membuktikan pengaruh penerapan selfassessment, pengetahuan wajib pajak, dan pemeriksaan pajak berpengaruh terhadap kepatuhan wajib pajak.

\section{Telaah Teori dan Pengembangan Hipotesis}

Konsekuensi dari penerapan self Assessment dengan memberikan kepercayaan kepada Wajib Pajak untuk menghitung, memperhitungkan, menyetor dan melaporkan serta mempertanggungjawabkan jumlah pajak tertentu adalah pengawasan. Implementasi dari pengawasan itu sendiri adalah berupa pemeriksaan yang dapat dilakukan dengan cara verifikasi, pemeriksaan sederhana dan pemeriksaan secara lengkap yang bertujuan untuk menguji sejauh mana Wajib Pajak telah melaksanakan kewajiban perpajakannya berupa kewajiban menggunakan bill tagihan yang telah dilegalisasi oleh Dinas Pelayanan Pajak Daerah, kewajiban untuk melakukan pembukuan, kewajiban untuk menghitung, menyetor (dengan Surat Setoran Pajak Daerah / SSPD) dan melaporkan (dengan Surat Pemberitahuan Pajak Daerah / STPD) sesuai dengan jumlah kewajiban yang harus dibayar dengan perhitungan yang sebenarnya.
Rustiyaningsih (2011) melakukan penelitian Faktor-faktor yang mempengaruhi Wajib Pajak. Analisis data yang dilakukan dengan menggunakan analisis regresi linier berganda. Variabel bebas yang digunakan adalah sistem self assessment, kualitas pelayanan, tingkat pendidikan, tingkat penghasilan dan persepsi Wajib Pajak terhadap sanksi perpajakan. variabel terikat yang digunakan adalah Kepatuhan Wajib Pajak. Hasil penelitiannya menyebutkan bahwa rendahnya pemahaman self assessment system, kualitas pelayanan, tingkat penghasilan dan persepsi Wajib pajak terhadap sanksi perpajakan berpengaruh positif dan signifikan terhadap kepatuhan Wajib Pajak.

Utami, dkk (2012) melakukan penelitian pengaruh faktor-faktor eksternal terhadap tingkat kepatuhan Wajib Pajak di lingkungan Kantor Pelayanan Pajak Pratama Semarang. Variabel bebas yang digunakan kesadaran membayar pajak, pengetahuan dan pemahaman peraturan pajak, persepsi atas efektivitas system perpajakan, dan kualitas pelayanan. Variabel terikat yang digunakan tingkat kepatuhan membayar pajak. Analisis data yang digunakan Korelasi Product Moment koefisien determinasi dengan program software SPSS. Hasil penelitiannya adalah kesadaran membayar pajak, pengetahuan dan pemahaman peraturan pajak, persepsi atas efektivitas sistem perpajakan, dan kualitas pelayanan berpengaruh positif dan signifikan terhadap kepatuhan membayar pajak.

Widodo (2010), melakukan penelitian mengenai pengaruh Moralitas dan budaya pajak terhadap kepatuhan pajak di Indonesia. Analisis data yang dilakukan dengan menggunakan tehnik analisis multivariat Structural Equation Modeling (SEM). Variabel bebas yang digunakan adalah Moralitas pajak yang meliputi Faktor demografi, kebanggaan nasional, tingkat partisipasi, tingkat kepercayaan, tingkat otonomi daerah dan desentralisasi, kondisi ekonomi dan budaya pajak yang meliputi: aparatur pajak dan wajib pajak, peraturan perpajakan dan budaya nasional sedangkan variabel terikat yang digunakan adalah tingkat kepatuhan Wajib Pajak yang terdiri dari kepatuhan formal dan kepatuhan material. Hasil 
penelitiannya adalah bahwa variabel moralitas pajak (tax morale) berpengaruh terhadap kepatuhan pajak (tax complience) baik secara parsial maupun silmutan, variabel budaya pajak (tax culture) berpengaruh terhadap kepatuhan pajak (tax complience) baik secara parsial maupun silmutan, variabel moralitas pajak (tax morale) dan budaya pajak (tax culture) berpengaruh terhadap kepatuhan pajak (tax complieance) baik secara parsial maupun silmutan.

Puri (2011) melakukan penelitian pengaruh pemeriksaan pajak terhadap kepatuhan material wajib pajak dan implikasinya terhadap penerimaan pajak di wilayah Bandung. Variabel bebas yang digunakan pemeriksaan pajak dan kepatuhan material wajib pajak. Variabel terikat yang digunakan penerimaan pajak. Analisis data yang digunakan Korelasi Product Moment koefisien determinasi dengan software SPSS 18. Hasil penelitiannya adalah pemeriksaan pajak dan kepatuhan material Wajib Pajak berpengaruh positif dan signifikan terhadap penerimaan pajak. Supadmi (2010) melakukan penelitian meningkatkan kepatuhan Wajib Pajak melalui kualitas pelayanan. Variabel bebas yang digunakan adalah Kepatuhan Wajib Pajak, variabel terikat adalah kualitas pelayanan.Analisis data yang digunakan dengan menggunakan regresi linier berganda. Hasil penelitiannya adalah kepatuhan Wajib Pajak berpengaruh positif terhadap kualitas pelayanan. Miladia (2010) melakukan penelitian analisis faktor-faktor yang mempengaruhi tax compliance Wajib Pajak badan pada perusahaan industri manufaktur di Semarang. Variabel bebas yang digunakan adalah sikap tax professional, niat tax professional, kondisi keuangan, fasilitas perusahaan dan iklim organisasi. Variabel terikat adalah kepatuhan Wajib Pajak Badan. Analisis data yang digunakan Regresi linier berganda dengan program Software SPSS 15. Hasil penelitiannya adalah sikap tax professional, niat tax professional, kondisi keuangan, fasilitas perusahaan dan iklim organisasi berpengaruh positif dan signifikan terhadap kepatuhan pajak badan.

Elia Mustikasari (2007) melakukan penelitian mengenei kajian impiris tentang kepatuhan wajib pajak badan di perusahaan industri pengolahan di Surabaya. Analisis data yang dilakukan dengan menggunakan teknik analisis Multivariat Structural Equation Modeling (SEM) dengan menggunakan program Amos 5. Variabel bebas yang digunakan adalah pengaruh sikap terhadap tidak kepatuhan, norma subyektif, kewajiban moral, kontrol keperilakuan yang dipersepsikan, niat tax profesional untuk berperilaku tidak patuh, persepsi tentang kondisi keuangan perusahaan, persepsi tentang fasilitas perusahaan dan persepsi tentang iklim keorganisasian. Variabel terikat yang digunakan adalah kepatuhan wajib pajak badan. Hasil penelitiannya adalah: Sikap terhadap ketidakpatuhan pajak, kontrol keperilakuan yang dipersepsikan, dan persepsi tentang fasilitas perusahaan berpengaruh positif dan signifikan terhadap kepatuhan pajak, sedangkan norma subyektif, kewajiban moral, persepsi tentang kondisi keuangan, persepsi tentang iklim organisasi, niat tax professional untuk berperilaku tidak patuh, dan ketidakpatuhan pajak badan memiliki pengaruh yang negatif terhadap kepatuhan pajak .

Irani (2007) melakukan penelitian analisis pelaksanaan pemeriksaan pajak dalam meningkatkan kepatuhan Wajib Pajak orang pribadi pada Kantor Pelayanan Pajak Pratama Jakarta Sawah Besar Satu. Variabel bebas yang digunakan adalah pemeriksaan pajak dan variable terikat kepatuhan wajib pajak. Deskriptif survei, pengujian kualitas data, pengujian asumsi klasik dengan menggunakan Software SPSS versi 17. Hasil penelitiannya adalah Pemeriksaan pajak berdampak positif terhadap kepatuhan Wajib Pajak. Benno (2003) melakukan penelitian tax morale and institution. Variabel bebas yang digunakan adalah Sistematis menganalisis efek formal dan informal dan Variabel terikat Novel untuk menganalisis pajakmoral.Analisis datayang digunakan World values survey dan International Program survey social. Hasil penelitiannya adalah Hak-hak demokrasi langsung, lokal otonomi dan kepercayaan dalam pemerintahan, pengadilan dan sistem hukum memiliki efek positif dan signifikan pada semangat pajak. 


\section{Metode}

Penelitian ini bersifat deskriptif analitik. Pengujian hipotesis menggunakan metode analisis jalur (path analysis) dengan bantuan software Lisrel 8.54. Pengumpulan data menggunakan kuesioner (sebagai alat pengumpulan data) dengan skala pengukuran Likert (data ordinal) yang ditransformasi ke dalam skala interval menggunakan Methods Succesive Interval (MSI).

\section{Hasil Penelitian dan Pembahasan}

Variabel Penerapan Self Assessment. Penerapan self assessment diukur menggunakan tiga indikator dan dioperasionalkan dalam empat butir pernyataan. Skor jawaban pada masingmasing indikator ditetapkan tingkat kategori skor jawaban responden mengenai self assesment system, yang disajikan pada tabel 1 .

Prosentase skor $75.75 \%$, nilai ini berkategori baik. Sedangkan indikator melaporkan pembayaran pajak secara rutin dan tepat waktu nilai skor aktual 749 , prosentase skor $74.9 \%$ dan berkategori baik. Berdasarkan rekapitulasi skor jawaban responden diatas, penerapan self assessment nilai skor aktual sebesar 3.022, skor ideal 4000 dengan prossentase skor $75.50 \%$. Hal ini menunjukkan bahwa penerapan self assesment yang memberikan kewenangan sendiri pada wajib pajak hotel dan restoran di lingkungan Sudin Pelayanan Pajak Kota Administrasi Jakarta Selatan memiliki nilai kategori baik.

Variabel Pengetahuan Wajib Pajak Pengetahuan Wajib Pajak diukur dengan tiga indikator dan dioperasionalkan dalam lima pertanyaan. Indikator memahami hak dan kewajiban sebagai wajib pajak memiliki skor aktual sebesar 1.663 dan prosentase skor $83.15 \%$ dengan kategori baik. Indikator mengerti dan memahami sanksi perpajakan memiliki nilai skor aktual sebesar 807 , prosentase skor $80.70 \%$ dengan kategori baik. Indikator mengetahui dan memahami pengisian memiliki skor actual 1.637, prosentase skor $81.85 \%$ dan berkategori baik. Selengkapnya dapat dilihat pada tabel 2.

Secara keseluruhan skor jawaban pengetahuan wajib pajak memiliki skor aktual 4.107 , skor ideal 5000, prosentase skor $82.14 \%$

Tabel 1. Prosentase Skor Penerapan Self Assessment

\begin{tabular}{llllll}
\hline \multirow{2}{*}{ No } & Indikator & $\begin{array}{l}\text { Skor } \\
\text { Aktual }\end{array}$ & $\begin{array}{l}\text { Skor } \\
\text { Ideal }\end{array}$ & \% Skor & Kategori \\
\hline 1 & Menghitung jumlah pajak yang sebenarnya & 1515 & 2000 & $75.75 \%$ & Baik \\
2 & Menyetor pajak secara rutin dan tepat waktu & 751 & 1000 & $75.10 \%$ & Baik \\
\multirow{2}{*}{3} & $\begin{array}{l}\text { Melaporkan pembayaran pajak secara rutin dan tepat } \\
\text { waktu }\end{array}$ & 749 & 1000 & $74.90 \%$ & \multirow{2}{*}{ Baik } \\
\hline \multirow{2}{*}{ Penerapan Self Assesment System } & 3.022 & 4000 & $75.50 \%$ & Baik \\
\hline
\end{tabular}

Sumber : Hasil pengolahan data 2013

Tabel 2. Prosentase Skor Pengetahuan Wajib Pajak

\begin{tabular}{llllll}
\hline No & Indikator & $\begin{array}{l}\text { Skor } \\
\text { Aktual }\end{array}$ & $\begin{array}{l}\text { Skor } \\
\text { Ideal }\end{array}$ & \% Skor & Kategori \\
\hline 1 & Memahami hak dan kewajiban sebagai wajib pajak & 1.663 & 2000 & 83.15 & Baik \\
2 & Mengerti dan memahami sangsi perpajakan & 807 & 1000 & $80.70 \%$ & Baik \\
3 & Mengetahui dan memahami pengisian SPT & 1.637 & 2000 & $81.85 \%$ & Baik \\
\hline & Pengetahuan Wajib Pajak & 4.107 & 5000 & $82.14 \%$ & Baik \\
\hline
\end{tabular}

Sumber: Hasil Pengolahan Data 2013 
dan berkategori baik. Hal ini menunjukkan bahwa dengan pengetahuan yang baik tentang pajak oleh wajib pajak akan mempermudah dalam melaksanakan peraturan perpajakan. Kemudahan ini karena wajib pajak memahami hak dan kewajiban sebagai wajib pajak, sanksi pajak dan faham dalam pengisian SPT pajak.

Variabel Pemeriksaan Pajak Pemeriksaan pajak diukur dengan empat indikator dan mengunakan delapan butir pernyataan. Nilai skor aktual meningkatkan kepatuhan secara sukarela sebesar 1.419, prosentase skor 70.97 dan berkategori baik. Indikator frekuensi pemeriksaan pajak nilai skor aktual sebesar 1.332, prosentase skor jawaban $66.60 \%$ dan berkategori cukup. Nilai skor aktual upaya merubah perilaku negatif menjadi positif sebesar 1.384, prosentase skor $69.20 \%$ dan berkategori baik. Sedangkan untuk indikator upaya melaksanakan pembukuan dan pencatatan dengan benar, nilai skor actual sebesar 1.324, prosentase skor jawaban $66.20 \%$. Selengkapnya dapat dilihat pada tabel 3.
Secara keseluruhan Pemeriksaan Pajak memiliki skor aktual sebesar 5.459, skor ideal 8000, prosentase skor $68.23 \%$ dan berkategori baik. Sehingga pemeriksaan pajak perlu dilakukan sebagai upaya peningkatan kepatuhan perilaku Wajib Pajak. 4) Variabel Kepatuhan Wajib Pajak Kepatuhan Wajib Pajak diukur dengan tujuh indikator dengan menggunakan 10 pernyataan. Dari ketujuh indikator ternyata hanya indikator pendaftaran wajib pajak masuk kategori baik dibandingkan dengan indikator yang lain yang hanya masuk kategori cukup. Nilai skor aktual indikator ini sebesar 682 , prosentase skor $68.2 \%$ dan berkategori baik. Hasil selengkapnya dapat dilihat pada tabel 4 .

Secara keseluruhan nilai kepatuhan Wajib Pajak memiliki nilai skor aktual sebesar 6420 , skor ideal 10.000 dengan prosentase skor $64.20 \%$ dan masuk kategori cukup. Hal ini menunjukkan bahwa Wajib Pajak yang melakukan pendaftaran, meyampaikan SPT tepat waktu, pembayaran,

Tabel 3. Prosentase Skor Pemeriksaan Pajak

\begin{tabular}{|c|c|c|c|c|c|}
\hline No & Indikator & $\begin{array}{l}\text { S k o r } \\
\text { Aktual }\end{array}$ & $\begin{array}{l}\text { S } \mathbf{k} \mathbf{o r} \\
\text { Ideal }\end{array}$ & \% Skor & Kategori \\
\hline 1 & Meningkatkan kepatuhan secara sukarela & 1.419 & 2000 & $70.97 \%$ & Baik \\
\hline 2 & Frekuensi pemeriksaan pajak & 1.332 & 2000 & $66.60 \%$ & Cukup \\
\hline 3 & Upaya merubah perilaku negative menjadi positif & 1.384 & 2000 & $69.20 \%$ & Baik \\
\hline \multirow[t]{2}{*}{4} & $\begin{array}{l}\text { Upaya melaksanakan pembukuan dan pencatatan } \\
\text { dengan benar }\end{array}$ & 1.324 & 2000 & $66.20 \%$ & Cukup \\
\hline & Pemeriksaan Pajak & 5.459 & 8000 & $68.23 \%$ & Baik \\
\hline
\end{tabular}

Sumber: Hasil Pengolahan Data 2013

Tabel 4. Prosentase Skor Kepatuhan Wajib Pajak

\begin{tabular}{llllll}
\hline No & Indikator & Skor Aktual & Skor Ideal & \% Skor & Kategori \\
\hline 1 & Pendaftaran wajib pajak & 682 & 1000 & $68.2 \%$ & Baik \\
2 & Penyampaian SPT tepat waktu & 670 & 1000 & $67 \%$ & Cukup \\
3 & Pembayaran pajak tepat waktu & 1.270 & 2000 & $63.50 \%$ & Cukup \\
4 & Pelaporan pajak tepat waktu & 1.219 & 2000 & $60.95 \%$ & Cukup \\
5 & Tidak memiliki tunggakan pajak & 622 & 1000 & $62.20 \%$ & Cukup \\
6 & Tidak melanggar peraturan perpajakan & 1294 & 2000 & $64.70 \%$ & Cukup \\
7 & Kesesuaian jumlah kewajiban pajak & 663 & 1000 & $66.30 \%$ & Cukup \\
& Kepatuhan Pajak & 6420 & 10000 & $64.20 \%$ & Cukup \\
\hline
\end{tabular}

Sumber: Hasil Pengolahan Data 2013 
pelaporan pajak tepat waktu, tidak memiliki tunggakan, tidak melanggar peraturan dan pembayaran sesuai jumlah pajak yang ditetapkan dengan kewajiban merupakan ukuran wajib pajak yang patuh/taat.

\section{Pengujian Hipotesis}

Pada bagian ini akan dilakukan pengujian hipotesis untuk menguji pengaruh penerapan self assessment, pengetahuan Wajib Pajak terhadap pemeriksaan pajak dan dampaknya pada kepatuhan Wajib Pajak Hotel dan Restoran di lingkungan Sudin Pelayanan Pajak Kota Administrasi Jakarta Selatan Pengujian hipotesis dilakukan berdasarkan data yang telah dihitung pada bagian sebelumnya. (1) Pengujian Hipotesis pertama. Hipotesis pertama yang akan diuji adalah pengaruh variabel penerapan self assessment dan pengetahuan Wajib Pajak terhadap pemeriksaan pajak pada Wajib Pajak hotel dan restoran di lingkungan Sudin Pelayanan Pajak Kota Administrasi Jakarta Selatan, baik secara bersama-sama maupun secara parsial. Pengujian hipotesis dimulai dari pengujian secara parsial dan dilanjutkan dengan pengujian secara simultan. (a) Pengaruh Penerapan Self Assessment terhadap Pemeriksaan Pajak. Rumusan hipotesis statistik sebagai berikut:

$$
\mathrm{H}_{0}: \rho \mathrm{zx}_{1}=0 \text { : Penerapan self assessment }
$$
tidak berpengaruh terhadap pemeriksaan pajak pada Wajib Pajak hotel dan restoran di lingkungan Sudin Pelayanan Pajak Kota Administrasi
Jakarta Selatan.

$$
\mathrm{H}_{\mathrm{a}}: \rho \mathrm{zx}_{1} \neq 0 \text { : Penerapan self assessment }
$$

berpengaruh terhadap pemeriksaan pajak pada Wajib Pajak hotel dan restoran di lingkungan Sudin Pelayanan Pajak Kota Administrasi Jakarta Selatan.

Nilai koefisien jalur variabel pengetahuan Wajib Pajak terhadap pemeriksaan pajak sebesar 0,53 , karena koefisien jalur variabel pengetahuan Wajib Pajak $(0,53)$ lebih besar dari nol, maka Ho ditolak dan Ha diterima. Hal ini membuktikan bahwa Penerapan self assessment berpengaruh terhadap pemeriksaan pajak pada Wajib Pajak hotel dan restoran di lingkungan Sudin Pelayanan Pajak Kota Administrasi Jakarta Selatan. (b) Pengaruh Pengetahuan Wajib Pajak Terhadap Pemeriksaan Pajak. Rumusan hipotesis sebagai berikut :

$\mathrm{H}_{0}: \rho \mathrm{zx}_{2}=0 \quad$ : Pengetahuan Wajib Pajak tidak berpengaruh terhadap pemeriksaan pajak pada Wajib Pajak hotel dan restoran di lingkungan Sudin Pelayanan Pajak Kota Administrasi Jakarta Selatan.

Ha: $\rho z_{1} \neq 0$ : Pengetahuan Wajib Pajak berpengaruh terhadap pemeriksaan pajak pada Wajib Pajak hotel dan restoran di lingkungan Sudin Pelayanan Pajak Kota Administrasi Jakarta Selatan.

Diperoleh nilai koefisien jalur variabel pengetahuan Wajib Pajak terhadap pemeriksaan pajak sebesar 0,53 , karena koefisien jalur variabel pengetahuan Wajib Pajak $(0,53)$ lebih besar dari

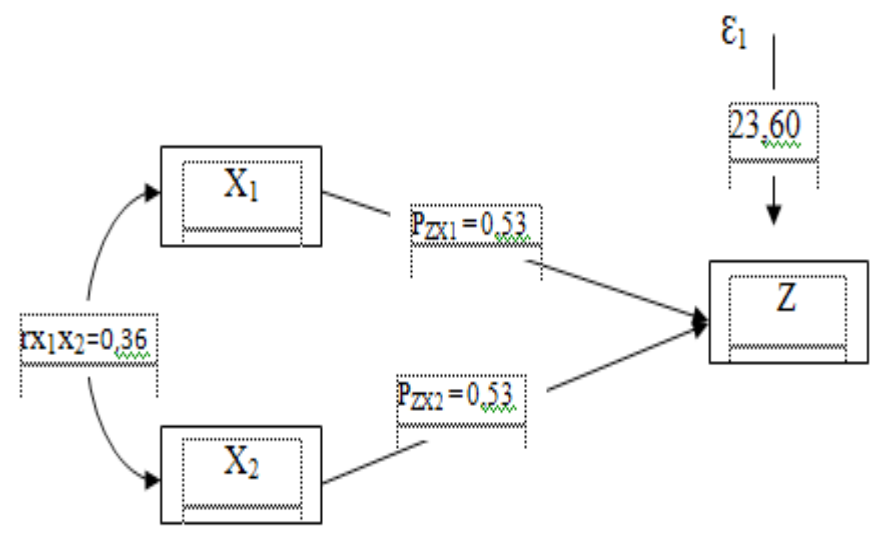

Gambar 1. Diagram jalur Self Assesment, Pengetahuan Pajak dan Pemeriksaan Pajak. 
nol, maka Ho ditolak dan Ha diterima sehingga disimpulkan bahwa pengetahuan Wajib Pajak berpengaruh terhadap pemeriksaan pajak pada Wajib pajak hotel dan restoran di lingkungan Sudin Pelayanan Pajak Kota Administrasi Jakarta Selatan. Semakin baik pengetahuan Wajib Pajak akan memudahkan pemeriksaan pajak.

(c) Pengaruh Penerapan Self Assessment dan Pengetahuan Wajib Pajak terhadap Pemeriksaan Pajak. Rumusan hipotesis sebagai berikut:

$\mathrm{H}_{0}$ : semua $\rho \mathrm{zx}_{2}=0$ : Penerapan self assessment dan pengetahuan Wajib Pajak tidak berpengaruh terhadap pemeriksaan pajak pada Wajib Pajak hotel dan restoran di lingkungan Sudin Pelayanan Pajak Kota Administrasi Jakarta Selatan.

Ha: semua $\rho \mathrm{zx}_{1} \neq 0$ : Penerapan self assessment dan pengetahuan Wajib Pajak berpengaruh terhadap pemeriksaan pajak pada Wajib Pajak hotel dan restoran di lingkungan Sudin Pelayanan Pajak Kota Administrasi Jakarta Selatan.

Nilai koefisien jalur dari kedua variabel bebas terhadap pemeriksaan pajak lebih besar dari nol. Dapat disimpulkan bahwa penerapan self assessment dan pengetahuan Wajib Pajak berpengaruh secara positif dan signifikan terhadap pemeriksaan pajak pada Wajib Pajak hotel dan restoran di lingkungan Sudin Pelayanan Pajak Kota Administrasi Jakarta Selatan.
(2) Pengujian Hipotesis Kedua. Pengujian hipotesis dilakukan secara langsung maupun tidak langsung. (a) Pengaruh Penerapan Self Assessment Terhadap Kepatuhan Wajib Pajak. Diduga variabel penerapan self assessment berpengaruh secara positif dan signifikan terhadap kepatuhan Wajib Pajak pada Wajib Pajak.

Rumusan hipotesis sebagai berikut:

$\mathrm{H}_{0}: \rho \mathrm{YX}_{1}=0$ : Penerapan selfassessment tidak berpengaruh terhadap kepatuhan Wajib Pajak pada Wajib Pajak hotel dan restoran di lingkungan Sudin Pelayanan Pajak Kota Administrasi Jakarta Selatan.

Pajak pada Wajib Pajak hotel dan restoran di lingkungan Sudin Pelayanan Pajak Kota Administrasi Jakarta Selatan.

Ha: $\rho \mathrm{YX}_{1} \neq 0$ : Penerapan self assessment berpengaruh terhadap kepatuhan Wajib Pajak pada Wajib Pajak hotel dan restoran di lingkungan Sudin Pelayanan Pajak Kota Administrasi Jakarta Selatan.

Diperoleh nilai koefisien jalur variabel penerapan self assessment terhadap kepatuhan Wajib Pajak sebesar 0,30. Koefisien jalur penerapan self assessment $(0,30)$ lebih besar dari nol, maka Ho ditolak dan Ha diterima. Dapat disimpulkan bahwa penerapan self assessment berpengaruh secara positif dan signifikan terhadap kepatuhan Wajib Pajak pada Wajib Pajak hotel dan restoran di lingkungan Sudin Pelayanan

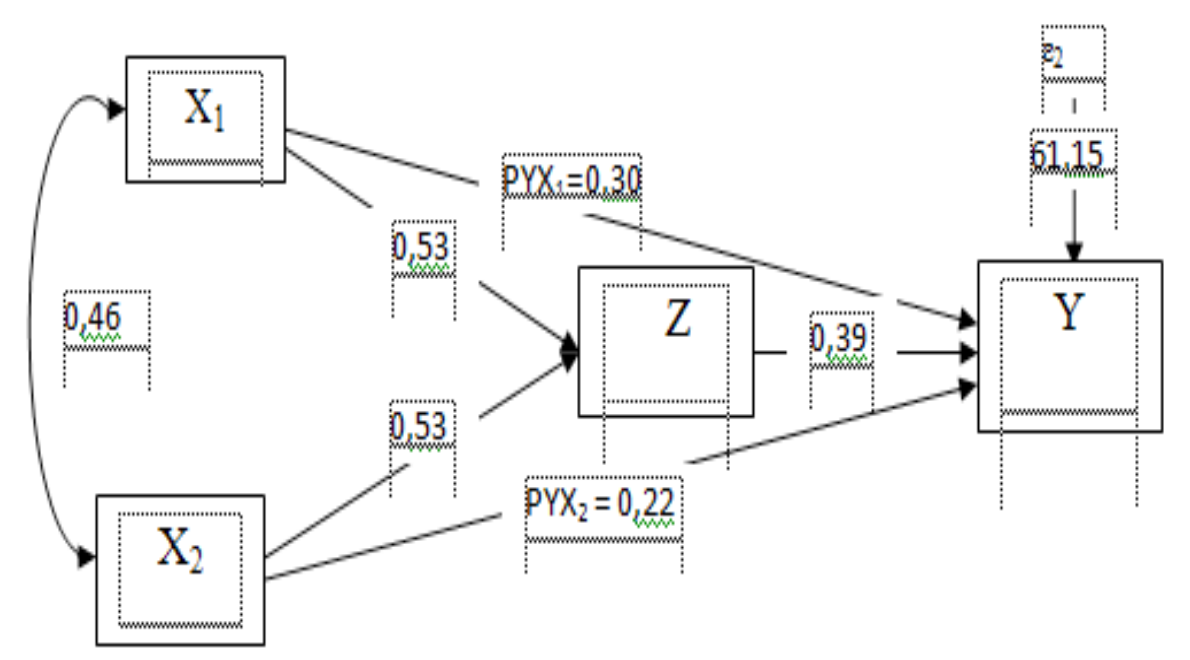

\section{Gambar 2. Diagram jalur Self Assesment, Pengetahuan Pajak, Pemeriksaan Pajak dan Kepatuhan pajak}


Pajak Kota Administrasi Jakarta Selatan. Dengan diterapkannya sistem self assessment akan meningkatkan kepatuhan Wajib Pajak pada Wajib Pajak hotel dan restoran di lingkungan Sudin Pelayanan Pajak Kota Administrasi Jakarta Selatan.

(b) Pengaruh Pengetahuan Wajib Pajak Terhadap Kepatuhan Wajib Pajak. Rumusan hipotesis sebagai berikut:

$\mathrm{H}_{0}: \rho \mathrm{YX}_{2}=0$ : Pengetahuan Wajib Pajak tidak berpengaruh terhadap kepatuhan Wajib Pajak pada Wajib Pajak hotel dan restoran di lingkungan Sudin Pelayanan Pajak Kota Administrasi Jakarta Selatan.

Ha: $\rho \mathrm{YX}_{2} \neq 0$ : Pengetahuan Wajib Pajak berpengaruh terhadap kepatuhan Wajib Pajak pada Wajib Pajak hotel dan restoran di lingkungan Sudin Pelayanan Pajak Kota Administrasi Jakarta Selatan.

Diperoleh nilai koefisien jalur variabel Pengetahuan Wajib Pajak terhadap kepatuhan Wajib Pajak sebesar 0,22, lebih besar daripada nol maka Ho ditolak dan Ha diterima. Dapat disimpulkan bahwa pengetahuan Wajib Pajak berpengaruh secara positif dan signifikan terhadap kepatuhan Wajib Pajak pada Wajib Pajak di lingkungan Sudin Pelayanan Pajak Kota Administrasi Jakarta Selatan. Semakin tinggi tingkat pengetahuan Wajib Pajak dalam melaksanakan kewajiban perpajakannya maka akan meningkatkan kepatuhan Wajib Pajak secara sukarela.

(c) Pengaruh Pemeriksaan Pajak terhadap kepatuhan wajib pajak. Rumusan Hipotesis sebagai berikut;

$\mathrm{H}_{0}: \rho z \mathrm{Y}=0$ : Pemeriksaan Pajak tidak berpengaruh terhadap Kepatuhan Wajib Pajak pada Wajib Pajak hotel dan restoran di lingkungan Sudin Pelayanan Pajak Kota Administrasi Jakarta Selatan.

Ha: $\rho$ zY $\neq 0$ : Pemeriksaan Pajak berpengaruh terhadap kepatuhan Wajib Pajak pada Wajib Pajak hotel dan restoran di lingkungan Sudin Pelayanan Pajak Kota Administrasi Jakarta Selatan.

Diperolehnilaikoefisienjalurpemeriksaan pajak terhadap kepatuhan Wajib Pajak sebesar
0,39 . Koefisien jalur variabel pemeriksaan pajak $(0,39)$ lebih besar dari nol, maka Ho ditolak dan Ha diterima. Dapat disimpulkan bahwa pemeriksaan pajak berpengaruh secara positif dan signifikan terhadap kepatuhan Wajib Pajak pada Wajib Pajak hotel.

(d) Pengaruh Penerapan Self Assessment, Pengetahuan Wajib Pajak dan Pemeriksaan Pajak Terhadap Kepatuhan Wajib Pajak. Rumusan hipotesis :

$\mathrm{H}_{0}:$ semua $\rho \mathrm{zx}_{1}=0:$ Penerapan self assessment, pengetahuan Wajib Pajak dan pemeriksaan pajak tidak berpengaruh terhadap kepatuhan Wajib Pajak pada Wajib Pajak hotel dan restoran di lingkungan Sudin Pelayanan Pajak Kota Administrasi Jakarta Selatan.

Ha: semua $\rho \mathrm{zx}_{1} \neq 0$ :Penerapan self assessment, pengetahuan Wajib Pajak dan pemeriksaan pajak berpengaruh terhadap kepatuhan Wajib Pajak pada Wajib Pajak hotel dan restoran di lingkungan Sudin Pelayanan Pajak Kota Administrasi Jakarta Selatan.

Diperoleh nilai koefisien jalur dari ketiga variabel terhadap kepatuhan Wajib Pajak lebih besar dari nol. Dapat disimpulkan bahwa penerapan self assessment, pengetahuan Wajib Pajak dan pemeriksaan pajak secara positif dan signifikan berpengaruh terhadap kepatuhan Wajib Pajak pada Wajib Pajak hotel dan restoran di lingkungan Sudin Pelayanan Pajak Kota Administrasi Jakarta Selatan.

\section{Pembahasan}

(1) Pengujian Hipotesis pertama. (a) Pengaruh Penerapan Self Assessment terhadap Pemeriksaan Pajak. Sehingga dapat disimpulkan bahwa variabel penerapan self assessment berpengaruh secara positif dan signifikan terhadap pemeriksaan pajak pada Wajib Pajak hotel dan restoran di lingkungan Sudin Pelayanan Pajak Kota Administrasi Jakarta Selatan.

Variabel penerapan self assessment memberikan kontribusi sebesar 28,09\% terhadap pemeriksaan pajak dan secara tidak langsung karena keterkaitannya dengan pengetahuan Wajib Pajak sebesar 10,11\%. Total kontribusi (pengaruh) variabel penerapan self assessment 
terhadap pemeriksaan pajak pada Wajib Pajak hotel dan restoran di lingkungan Sudin Pelayanan Pajak Kota Administrasi Jakarta Selatan sebesar $38,20 \%$.

Hasil penelitian ini dapat dimaknai bahwa penerapan self assessment berpengaruh terhadap pemeriksaan pajak. Relevan dengan pendapat Rustiyaningsih (2011), semakin intens pemeriksaan pajak dilakukan maka penerapan self assessment akan semakin baik, dan sebaliknya semakin jarang pemeriksaan dilakukan maka akan semakin rendah kualitas sistem self assessment yang diterapkan untuk dilaksanakan oleh Wajib Pajak.

Faktor yang paling berpengaruh dalam penerapan sistem self assessment adalah kejujuran Wajib Pajak dalam menghitung jumlah pajak yang sebenarnya, menyetor dan melaporkan pembayaran pajak tepat waktu ( Rata-rata $75 \%$ ) berkategori baik, yang menunjukkan bahwa Wajib Pajak hotel dan restoran di lingkungan Sudin Pelayanan Pajak Kota Administrasi Jakarta Selatan sudah menyadari kewajiban perpajakannya dan sanksi administrasi yang diterima ketika kewajiban perpajakannya tidak dilaksanakan dengan baik.

(b) Pengaruh Pengetahuan Wajib Pajak Terhadap Pemeriksaan Pajak. Sehingga disimpulkan bahwa pengetahuan Wajib Pajak berpengaruh terhadap pemeriksaan pajak pada Wajib pajak hotel dan restoran di lingkungan Sudin Pelayanan Pajak Kota Administrasi Jakarta Selatan. Semakin baik pengetahuan Wajib Pajak akan memudahkan pemeriksaan pajak.

Secara langsung variabel pengetahuan Wajib Pajak memberikan kontribusi sebesar 28,09\% terhadap pemeriksaan pajak dan secara tidak langsung karena keterkaitannya dengan sistem penerapan self assessment sebesar $10,11 \%$. Total kontribusi (pengaruh) variabel pengetahuan Wajib Pajak terhadap pemeriksaan pajak pada Wajib Pajak hotel dan restoran di lingkungan Kota Administrasi Jakarta Selatan sebesar $38,20 \%$.

Hasil penelitian ini menunjukkan pengetahuan Wajib Pajak berpengaruh secara positif dan signifikan terhadap pemeriksaan pajak. Relevan dengan dengan penelitian Utami et all (2012), yang menyatakan bahwa semakin tinggi tingkat pengetahuan Wajib Pajak tentang kewajibanperpajakannyamakaakanmemudahkan pemeriksaan pajak dan meningkatkan kualitas pemeriksaan pajak.

Faktor yang paling berpengaruh pada pengetahuan Wajib Pajak adalah peningkatan pengetahuan Wajib Pajak yang dilakukan oleh fiskus sehingga Wajib Pajak dapat memahami pengisian SPT, memahami hak dan kewajiban serta sanksi perpajakan. Wajib Pajak Hotel dan Restoran di lingkungan Sudin Pelayanan Pajak Kota Administrasi Jakarta Selatan (Rata-rata $80 \%$ ), berkategori baik. Menunjukkan bahwa pengetahuanyang baiktentang pajakmemudahkan Wajib Pajak dalam melaksanakan kewajiban perpajakan dan meningkatkan pemeriksaan pajak. (c) Pengaruh Penerapan Self Assessment dan Pengetahuan Wajib Pajak Terhadap Pemeriksaan Pajak. Dapat disimpulkan bahwa penerapan self assessment dan pengetahuan Wajib Pajak berpengaruh secara positif dan signifikan terhadap pemeriksaan pajak pada Wajib Pajak hotel dan restoran di lingkungan Sudin Pelayanan Pajak Kota Administrasi Jakarta Selatan.

Melalui penjumlahan besar pengaruh kedua variabel bebas secara parsial akan diperoleh besarnya pengaruh kedua variabel bebas secara bersama-sama. Total pengaruh variabel penerapan self assessment dan pengetahuan Wajib Pajak secara bersama-sama terhadap pemeriksaan pajak pada Wajib Pajak di lingkungan Sudin Pelayanan Pajak Kota Administrasi Jakarta Selatan = $38,20 \%+38,20 \%=76,40 \%$. Artinya $76,40 \%$ pemeriksaan pajak pada Wajib Pajak hotel dan restoran di lingkungan Kota Administrasi Jakarta Selatan disebabkan adanya penerapan sistem self assessment dan pengetahuan Wajib Pajak. sementara $23,60 \%$ sisanya dipengaruhi oleh faktor-faktor lain diluar variabel tersebut. Secara empiris telah terbukti bahwa variabel penerapan self assessment dan pengetahuan Wajib Pajak secara langsung maupun secara tidak langsung berpengaruh terhadap pemeriksaan pajak. Relevan dengan penelitian Rustiyaningsih (2011), bahwa pemahaman self assessment dan persepsi Wajib 
Pajak terhadap sanksi perpajakan berpengaruh positif dan signifikan terhadap kepatuhan Wajib Pajak.

Hasil penelitian ini dapat diartikan bahwa pemeriksaan pajak yang baik, benar dan intensif sangat berperan bagi keberhasilan penerapan self assessment dan peningkatan pengetahuan Wajib Pajak dalam melaksanakan kewajiban perpajakannya. Semakin baik pemeriksaan pajak di lakukan semakin baik pula tingkat penerapan self assessment dan pengetahuan Wajib Pajak.

(2) Pengujian Hipotesis Kedua. (a) Pengaruh Penerapan Self Assessment Terhadap Kepatuhan Wajib Pajak. Dapat disimpulkan bahwa penerapan self assessment berpengaruh secara positif dan signifikan terhadap kepatuhan Wajib Pajak pada Wajib Pajak hotel dan restoran di lingkungan Sudin Pelayanan Pajak Kota Administrasi Jakarta Selatan. Dengan diterapkannya sistem self assessment akan meningkatkan kepatuhan Wajib Pajak pada Wajib Pajak hotel dan restoran di lingkungan Sudin Pelayanan Pajak Kota Administrasi Jakarta Selatan.

Penerapan self assessment secara langsung memberikan kontribusi sebesar 9\% terhadap kepatuhan Wajib Pajak dan secara tidak langsung karena keterkaitannya dengan pengetahuan Wajib Pajak dan pemeriksaan pajak sebesar 8,42\%. Total kontribusi (pengaruh) variabel penerapan self assessment terhadap kepatuhan Wajib Pajak pada Wajib Pajak hotel dan restoran di lingkungan Sudin Pelayanan Pajak Kota Administrasi Jakarta Selatan sebesar $17,42 \%$.

Penerapan self assessment secara empiris berpengaruh terhadap terhadap kepatuhan Wajib Pajak. Relevan dengan hasil penelitian Utami et.all (2012) bahwa kesadaran membayar pajak berpengaruh positif terhadap tingkat kepatuhan membayar pajak. Hasil penelitian ini juga mendukung penelitian Rustiyaningsih (2011), yang menyatakan pemahaman self assessment yang baik berpengaruh positif dan signifikan terhadap kepatuhan Wajib Pajak.

(b) Pengaruh Pengetahuan Wajib Pajak Terhadap Kepatuhan Wajib Pajak. Dapat disimpulkan bahwa pengetahuan Wajib Pajak berpengaruh secara positif dan signifikan terhadap kepatuhan Wajib Pajak pada Wajib Pajak di lingkungan Sudin Pelayanan Pajak Kota Administrasi Jakarta Selatan. Semakin tinggi tingkat pengetahuan Wajib Pajak dalam melaksanakan kewajiban perpajakannya maka akan meningkatkan kepatuhan Wajib Pajak secara sukarela.

Pengetahuan Wajib Pajak memberikan kontribusi (pengaruh) sebesar 4,84\% terhadap kepatuhan Wajib Pajak dan secara tidak langsung karena keterkaitannya dengan penerapan self assessment dan pemeriksaan pajak sebesar 7,24\%. Total kontribusi (pengaruh) variabel penerapan self assessment terhadap kepatuhan Wajib Pajak pada Wajib Pajak hotel dan restoran di lingkungan Sudin Pelayanan Pajak Kota Administrasi Jakarta Selatan sebesar $12,08 \%$.

Pengetahuan Wajib Pajak berpengaruh terhadap terhadap kepatuhan Wajib Pajak. Relevan dengan hasil penelitian Utami et.all (2012) bahwa pengetahuan dan pemahaman tentang peraturan perpajakan berpengaruh positif terhadap tingkat kepatuhan membayar pajak. hasil penelitian ini juga sejalan dengan Rustiyaningsih (2011), yang menyatakan bahwa persepsi Wajib Pajak terhadap sanksi perpajakan berpengaruh positif dan signifikan terhadap kepatuhan Wajib Pajak.

Hasil penelitian ini telah membuktikan secara empiris dan didukung oleh hasil penelitian sebelumnya bahwa semakin tinggi tingkat pemahaman dan pengetahuan Wajib Pajak dalam memenuhi kewajiban perpajakannya maka semakin baik tingkat kepatuhan membayar pajak secara sukarela.

(c) Pengaruh Pemeriksaan Pajak terhadap Kepatuhan Wajib Pajak. Dapat disimpulkan bahwa pemeriksaan pajak berpengaruh secara positif dan signifikan terhadap kepatuhan Wajib Pajak pada Wajib Pajak hotel dan restoran di lingkungan Sudin Pelayanan Pajak Kota Administrasi Jakarta Selatan.

Pemeriksaan pajak secara langsung memberikan kontribusi (pengaruh) sebesar $51,21 \%$ terhadap kepatuhan Wajib Pajak dan secara tidak langsung karena keterkaitannya dengan variabel penerapan self assessment 
dan pengetahuan Wajib Pajak sebesar 9,24\%. Total kontribusi (pengaruh) pemeriksaan pajak terhadap kepatuhan Wajib Pajak pada Wajib Pajak hotel dan restoran di lingkungan Sudin Pelayanan Pajak Kota Administrasi Jakarta Selatan sebesar $60,45 \%$.

Pemeriksaan Pajak berpengaruh terhadap kepatuhan Wajib Pajak. Relevan dengan hasil penelitian Irani (2012) bahwa pemeriksaan pajak berdampak positif terhadap kepatuhan Wajib Pajak. Hasil penelitian ini sesuai dengan penelitian Puri (2011) yang menyatakan bahwa hasil pemeriksaan pajak berpengaruh terhadap kepatuhan material Wajib Pajak.

Hasil penelitian ini telah membuktikan secara empiris dan didukung oleh hasil penelitian sebelumnya bahwa semakin intensif pemeriksaan pajak dilakukan maka semakin baik tingkat kepatuhan membayar pajak secara sukarela. (D) Pengaruh Penerapan Self Assessment, Pengetahuan Wajib Pajak dan Pemeriksaan Pajak Terhadap Kepatuhan Wajib Pajak. Dapat disimpulkan bahwa penerapan self assessment, pengetahuan Wajib Pajak dan pemeriksaan pajak secara positif dan signifikan berpengaruh terhadap kepatuhan Wajib Pajak pada Wajib Pajak hotel dan restoran di lingkungan Sudin Pelayanan Pajak Kota Administrasi Jakarta Selatan.

Pengaruh penerapan self assessment, pengetahuan Wajib Pajak dan pemeriksaan pajak terhadap kepatuhan Wajib Pajak secara bersamasama terhadap kepatuhan Wajib Pajak pada Wajib Pajak di lingkungan Kota Administrasi Jakarta Selatan $=17,42 \%+12,08 \%+60,45 \%=90,67 \%$. Artinya 90,67\% kepatuhan Wajib Pajak pada Wajib Pajak hotel dan restoran di lingkungan Sudin Pelayanan Pajak Kota Administrasi Jakarta Selatan disebabkan karena penerapan sistem self assessment, tingkat pengetahuan Wajib Pajak dan pemeriksaan pajak. Sisanya sebesar 9,33\% disebabkan variabel lain diluar ketiga variabel tersebut, yaitu variabel pengawasan dengan sistematis, alokasi anggaran yang bersumber dari pajak, Sumber Daya Manusia, Sumber Daya dan prasarana, kesadaran Wajib Pajak, tingkat moralitas Wajib Pajak dan kondisi ekonomi Wajib Pajak.
Penerapan self assessment, pengetahuan Wajib Pajak dan pemeriksaan pajak terbukti secara empiris berpengaruh terhadap kepatuhan Wajib Pajak. Relevan dengan hasil penelitian Utami et.all (2012) yang menyatakan bahwa kesadaran membayar pajak, pengetahuan dan pemahaman tentang peraturan perpajakan berpengaruh positif terhadap kepatuhan membayar pajak. Hasil penelitian Rustiyaningsih (2011) yang menyatakan rendahnya pemahaman self assessment system berpengaruh positif dan signifikan terhadap kepatuhan Wajib Pajak,dan hasil penelitian Iriani (2012) menyatakan pemeriksaan pajak berdampak positif terhadap kepatuhan Wajib Pajak.

Penelitian-penelitian ini menunjukkan bahwa Penerapan self assessment yang baik, pengetahuan Wajib Pajak yang terus ditingkatkan dengan disertai pemeriksaan yang intensif maka kepatuhan Wajib Pajak secara suka rela akan meningkat.

\section{Simpulan, Keterbatasan dan Implikasi Hasil Penelitian}

Penerapan sistem self assessment yang memberikan kepercayaan kepada Wajib Pajak Hotel dan Restoran di lingkungkan Sudin Pelayanan Pajak Kota Administrasi Jakarta Selatan untuk menghitung, memperhitungkan, meyetorkan dan melaporkan pajaknya sendiri perlu dilakukan tindakan pengawasan yaitu pemeriksaan pajak. Semakin intens pemeriksaan pajak dilakukan maka penerapan self assessment semakin baik.

Pengetahuan Wajib Pajak berpengaruh secara positifdan signifikan terhadap pemeriksaan pajak. Hal ini menunjukkan bahwa semakin tinggi tingkat pengetahuan Wajib Pajak Hotel dan Restoran di lingkungan Sudin Pelayanan Pajak Kota Administrasi Jakarta Selatan maka semakin baik dan mudah pemeriksaan pajak di lakukan.

Penerapan self assessment berpengaruh secara positif dan signifikan terhadap kepatuhan Wajib Pajak. Ini menunjukkan bahwa dengan diterapkannya sistem self assessment akan meningkatkan kepatuhan Wajib Pajak Hotel 
dan Restoran di lingkungan Sudin Pelayanan Pajak Kota Administrasi Jakarta Selatan secara sukarela.

Pengetahuan Wajib Pajak berpengaruh secara positif dan signifikan terhadap kepatuhan Wajib Pajak. Hal ini menunjukkan bahwa semakin tinggi tingkat pengetahuan Wajib Pajak memahami kewajiban perpajakannya maka semakin mudah dan efektif bagi Wajib Pajak Hotel dan Restoran di lingkungan Sudin Pelayanan Pajak Kota Administrasi Jakarta Selatan dalam melaksanakan kewajiban perpajakannya.

Pemeriksaan pajak berpengaruh secara positif dan signifikan terhadap kepatuhan Wajib Pajak. Hal ini menunjukkan bahwa kepatuhan Wajib Pajak akan meningkat jika pemeriksaan pajak dilakukan secara intensif dan komprehensif. Karena sanksi yang jelas dapat menimbulkan keengganan Wajib Pajak untuk melakukan pelanggaran.

Penerapan self assessment yang baik, pengetahuan wajib pajak yang terus ditingkatkan dengan disertai pemeriksaan pajak yang baik dan intensif maka kepatuhan Wajib Pajak secara sukarela akan meningkat.

\section{Saran}

Kejujuran dan kesadaran Wajib Pajak dalam melaksanakan sistem self assessment harus bersamaan dengan pemeriksaan pajak yang rutin dan intensif sehingga penerapan self assessment dapat berjalan dengan benar sesuai dengan prosedur yang berlaku.

Disarankan kepada Sudin Pelayanan Pajak Kota Administrasi Jakarta Selatan untuk meningkatkan pengetahuan Wajib Pajak, sehingga Wajib Pajak semakin mengerti dan patuh dalam memenuhi kewajiban perpajakannya yang sudah tentu akan meningkatkan penerimaan pajak daerah. Pemeriksaan pajak memerlukan pengorbanan tenaga, waktu dan biaya yang relatif besar serta resiko tinggi berupa timbulnya resistensi Wajib Pajak dan sengketa pajak, maka aktivitas pendukung pemeriksaan pajak sebaiknya dilakukan secara terencana dan berkesinambungan oleh Sudin Pelayanan Pajak Kota Administrasi Jakarta Selatan dengan pengawasan dan bimbingan dari Dinas Pelayanan Pajak Provinsi DKI Jakarta.

Disarankan kepada Sudin Pelayanan Pajak Kota Administrasi Jakarta Selatan untuk terus meningkatkan kemampuan Sumber Daya Manusia baik dari segi performance maupun skill, sehingga didapati pemeriksaan pajak yang kompeten.

Penelitian ini menggunakan uji analisa dengan analisa jalur (path analysis) disarankan kepada peneliti selanjutnya untuk menggunakan uji analisa SEM sehingga dapat dijadikan pembanding.

Adanya nilai Epsilon yang berjumlah tujuh variabel yaitu pengawasan dengan sistematis, alokasi anggaran yang bersumber dari pajak, Sumber Daya Manusia, Sumber Daya dan Prasarana, kesadaran Wajib Pajak, tingkat moralitas Wajib Pajak dan kondisi ekonomi Wajib Pajak dari model penelitian ini yang menunjukkan bahwa masih ada variabel lain yang mempengaruhi kepatuhan Wajib Pajak, maka disarankan kepada peneliti selanjutnya untuk mengkaji varibel-variabel lain tersebut.

\section{Daftar Rujukan}

Hutagaol, 2007. Isu-Isu Kontemporer, Edisi Pertama. Yogyakarta. . Graha Ilmu

Undang- Undang Nomor 28 Tahun 2009

Rustiyaningsih, 2011. Faktor-Faktor yang Mempengaruhi Kepatuhan Wajib Pajak. Jurnal Skripsi.

Peraturan Daerah (Perda) DKI Jakarta Nomor 6 Tahun 2010

Utami,.et,.al, 2012. Pengaruh Faktor-Faktor Eksternal terhadap Tingkat Kepatuhan Wajib Pajak (Studi Kasus di Kantor Pelayanan Pajak Pratama Semarang). Jurnal Tesis.

Safri Nurmantu, 2005. Pengantar Perpajakan (Edisi 3). Jakarta. Granit

Novita Miladia, 2010. Analisis Faktor-Fkator yang mempengaruhi Tax Compliance Wajib Pajak Badan (Studi Kasus Pada Perusahaan Industri Manufaktur di Semarang. Jurnal Skripsi

Mustikasari, 2007. Kepatuhan Wajib Pajak Badan 
(Kajian Empiris di perusahaan Industri Pengolahan di Surabaya). Simposium Nasional Akuntansi. Unhas Makasar. 